\title{
The livelihood impacts of the Equitable Payments for Watershed Services (EPWS) Program in Morogoro, Tanzania
}

\author{
EMMANUEL J. KWAYU \\ Department of Geography and Economics, Dar es Salaam University College \\ of Education, University of Dar es Salaam, Tanzania; and Sustainability \\ Research Institute, School of Earth and Environment, University of Leeds, \\ UK. Tel: +255718203803. Fax: +441133435259. \\ Email:eeejk@leeds.ac.uk, ejkwayu@yahoo.co.uk
}

JOUNI PAAVOLA

Sustainability Research Institute, School of Earth and Environment, University of Leeds, Leeds, UK.

Email: j.paavola@leeds.ac.uk

\author{
SUSANNAH M. SALLU \\ Sustainability Research Institute, School of Earth and Environment, \\ University of Leeds, Leeds, UK. \\ Email: s.sallu@leeds.ac.uk
}

Submitted 8 July 2014; revised 9 July 2016, 5 December 2016; accepted 5 January 2017

\begin{abstract}
Research on PES programs in agro-ecosystems is recent and limited in developing countries. The authors use a multi-method, quasi-experimental impact evaluation approach to examine direct and indirect livelihood impacts of the Equitable Payments for Watershed Services (EPWS) program piloted in the Morogoro region in Tanzania. The evaluation is based on a survey of 116 program participants and 117 non-participants, 32 semi-structured interviews and 16 focus group discussions to complement the survey data. They find that, while the EPWS program incentives resulted in direct benefits, indirect benefits such as increased crop yields, higher land values, new employment opportunities, more knowledgeable farmers, improved leadership skills as
\end{abstract}

The authors thank the University of Dar es Salaam on behalf of the Tanzania Commission for Science and Technology for granting permission to conduct this research. They thank EPWS-Morogoro staff, local community leaders, local government officers, farmers and enumerators for their support and participation in fieldwork. They gratefully acknowledge the support of the Government of Tanzania, Dar es Salaam University College of Education (DUCE) and the School of Earth and Environment, University of Leeds for funding this study. 
well as increased trust, expanded internal and external networks and strengthened institutions were more important. The results clearly indicate the potential of PES schemes to generate win-win outcomes in agro-ecosystems, but they also call for attention to equity in the design of PES programs implemented on agro-ecosystems.

\section{Introduction}

The attractiveness of Payment for Ecosystem Services (PES) schemes to restore, protect, secure or enhance the supply of ecosystem services and to alleviate poverty in the agricultural ecosystems of developing countries has recently increased (Wunder, 2005, 2007; Pagiola and Platais, 2007; Engel et al., 2008; Sommerville et al., 2009; Scales, 2015). However, PES remains a contested conservation approach. PES is a market-based approach with a 'buyer' and 'seller' of a 'well-defined ecosystem service' (Wunder, 2005: 3). While some researchers consider PES a neoliberal policy with negative implications for the marginalized and the global South (McAfee and Shapiro, 2010; Dempsey and Robertson, 2012; Wunder, 2015), others consider it an effective and efficient mechanism for the provision of ecosystem services (Wunder, 2007; Engel et al., 2008; Molnar et al., 2008; Tacconi et al., 2010; Vatn, 2010). Also, while poverty alleviation and rural development are considered by some to be the only potential side benefits of PES (Wunder, 2006, 2008), others believe that social and environmental goals are intrinsically linked and should be on an equal footing in PES design (Corbera and Pascual, 2012; Singh, 2015). As such, there have been calls for a broader definition of PES encompassing markets, subsidies and other strategies for aligning individual and collective land use decisions and broader social interests in managing natural resources (Sommerville et al., 2009; Miranda et al., 2003).

Numerous PES initiatives ranging from local initiatives for conserving watersheds to regional and global arrangements for biodiversity and carbon sequestration services have been implemented worldwide (LandellMills and Porras, 2002; Corbera et al., 2007; Wunder et al., 2008). Further initiatives exist for landscape beauty and bundles of several ecosystem services (Landell-Mills and Porras, 2002; Clot et al., 2014). There is also growing interest in implementing PES schemes in agro-ecosystems of developing countries to achieve conservation and livelihood objectives simultaneously (Hope et al., 2005; Wunder, 2006, 2008; FAO, 2007b; Cole, 2010; Branca et al., 2011). Paying the poor for adopting sustainable land management (SLM) practices could ensure the provision of ecosystem services, improve livelihoods and alleviate poverty, because the poor often live in areas of low agricultural potential with poor soils, steep slopes, insecure land tenure and lack of access to credit (FAO, 2007b; Bulte et al., 2008; Corbera et al., 2009; Branca et al., 2011; Matzdorf and Meyer, 2014). The poor also often lack knowledge about new farming technologies and can be discouraged by temporary negative economic returns associated with transitions from old production systems to new ones (FAO, 2007a; TerrAfrica, 2007; Branca et al., 2011; Liniger et al., 2011).

Yet despite the growing interest in implementing PES to improve livelihoods and alleviate poverty in agro-ecosystems of developing countries, 
limited attention has been given to developing better understanding of the perils and promises of adoption of the new and largely untested conservation approach (Redford and Adams, 2009; Brockington, 2011). We seek to contribute to filling this gap in the literature by examining the direct and indirect livelihood impacts of the Equitable Payments for Watershed Services (EPWS) program piloted in Morogoro, Tanzania. We use a multi-method, quasi-experimental research design drawing from both quantitative and qualitative data and analysis. Our findings indicate that, while the direct financial payments to program participants for adopting SLM practices contribute to their livelihoods, the program's indirect financial and non-financial benefits are even more important. In the next section we review existing studies on PES and livelihoods and then outline our evaluation approach and material collection and analysis solutions. We then report our findings and relate them back to the literature in the discussion section.

\section{PES and livelihoods}

Although PES was not designed for improving livelihoods or alleviating poverty, research on its livelihood impacts has grown in recent years (Landell-Mills and Porras, 2002; Miranda et al., 2003; Grieg-Gran et al., 2005; Locatelli et al., 2008; Tacconi et al., 2010, 2011). The findings indicate that a PES program can affect rural livelihoods directly and indirectly. Directly, program participants receive payments for adopting land use changes or improved land use practices specified by the program (Pagiola et al., 2005; Molnar et al., 2008). In the Latin American PES programs reviewed by Wunder (2006), payments to participants formed from 10 to 50 per cent of their annual household cash income. These payments are a stable source of cash for investing in, for example, land productivity (Grieg-Gran et al., 2005; Corbera et al., 2007; Tacconi et al., 2010; Wunder et al., 2014).

Indirect impacts of PES programs include improvements to land tenure security and increases in the use of marginal land for tree planting, particularly when opportunity costs are lower than PES payments (Grieg-Gran et al., 2005; Pagiola et al., 2005). PES programs have also been shown to increase the capacity of participants through training, technical support and extension services (Tacconi et al., 2010). They have also increased labor demand (Caplow et al., 2011), improved the availability of and access to non-timber forest products and land, as well as contributing to social and cultural aspects of communities (Pagiola et al., 2005; Tacconi et al., 2010). Moreover, PES programs have forged internal and external relationships within communities (Grieg-Gran et al., 2005; Pagiola et al., 2005). For example, the implementation of the Pimampiro PES program in Ecuador increased the institutional capacity of the Nueva America community, enabling them to influence their municipality's decision to enforce environmental regulations (Echavarria et al., 2002).

Most studies on the livelihood impacts of PES have focused on programs implemented in forest ecosystems for reforestation, afforestation and forest protection (Landell-Mills and Porras, 2002; Grieg-Gran et al., 2005; Pagiola et al., 2005; FAO, 2007a; Porras et al., 2008; Wunder, 2008; 
Tacconi et al., 2010). This is because the majority of PES programs in developing countries are implemented in forest ecosystems rather than in agro-ecosystems (Zilberman et al., 2008; Tachibana and Adhikari, 2009). However, the potential of agro-ecosystems to restore or provide valuable ecosystem services is increasingly acknowledged (FAO, 2007b; Cole, 2010; Branca et al., 2011; Smith and Sullivan, 2014). For example, the Intergovernmental Panel on Climate Change (2007) estimated that by 2030 the agricultural sector in developing countries could contribute up to $1.9 \mathrm{Gt} / \mathrm{yr}$ of $\mathrm{CO}_{2}$ equivalent to carbon mitigation, and the forestry sector another $1.6 \mathrm{Gt} / \mathrm{yr}$. That is, there is substantial potential for carbon sequestration initiatives on agro-forestry and conservation agriculture, which could enhance natural resource-based livelihoods and increase smallholders' resilience to drought, climate change and economic instability (Stevenson et al., 2014).

Existing PES studies also highlight the growing integration of the livelihood approach to broaden the PES programs so that they acknowledge all those natural, human, financial, sociopolitical and physical assets that are central to livelihoods (Chambers and Conway, 1992; Echavarria et al., 2002; Ellis and Freeman, 2005; Tacconi et al., 2010). However, the majority of impact studies rely on anecdotal evidence or information gathered only from participating households which may be biased and lead to incomplete assessment of livelihood impacts (Ferraro and Simpson, 2002; Pagiola, 2005; Ferraro and Pattanayak, 2006; Pattanayak, 2009; Brown et al., 2011). Most studies do not differentiate the impacts of PES programs from the impacts of other development efforts (Asquith et al., 2002, 2008; Engel et al., 2008; Jindal, 2006; Wunder and Albán, 2008). The assessment of what would have happened to the livelihoods of program participants without the PES intervention is vital in order to inform the increasing number of PES programs and plans to invest billions of dollars in activities aimed at enhancing the provision of ecosystem services such as water regulation and carbon sequestration in developing countries (FAO, 2007a; Miles and Kapos, 2008; Ferraro, 2009; Schomers and Matzdorf, 2013).

To this end, this paper examines the direct and indirect livelihood impacts of the EPWS program for adopting SLM practices in Morogoro, Tanzania. We use a multi-method, quasi-experimental research design drawing from both quantitative and qualitative data and analysis. Our findings indicate that, while the direct financial payments to program participants for adopting SLM practices contribute to their livelihoods, the program's indirect financial and non-financial benefits are even more important.

\section{Case study, materials and methods}

The EPWS program led by CARE and WWF was piloted between 2008 and 2012 in the Kibungo juu ward of Morogoro region in Tanzania (figure 1). It was targeted at upstream farmers in the upper catchment of the Ruvu River in the Uluguru Mountains, the source of water supply to Dar-esSalaam (Branca et al., 2011; Lopa et al., 2012). The Dar-es-Salaam Water 


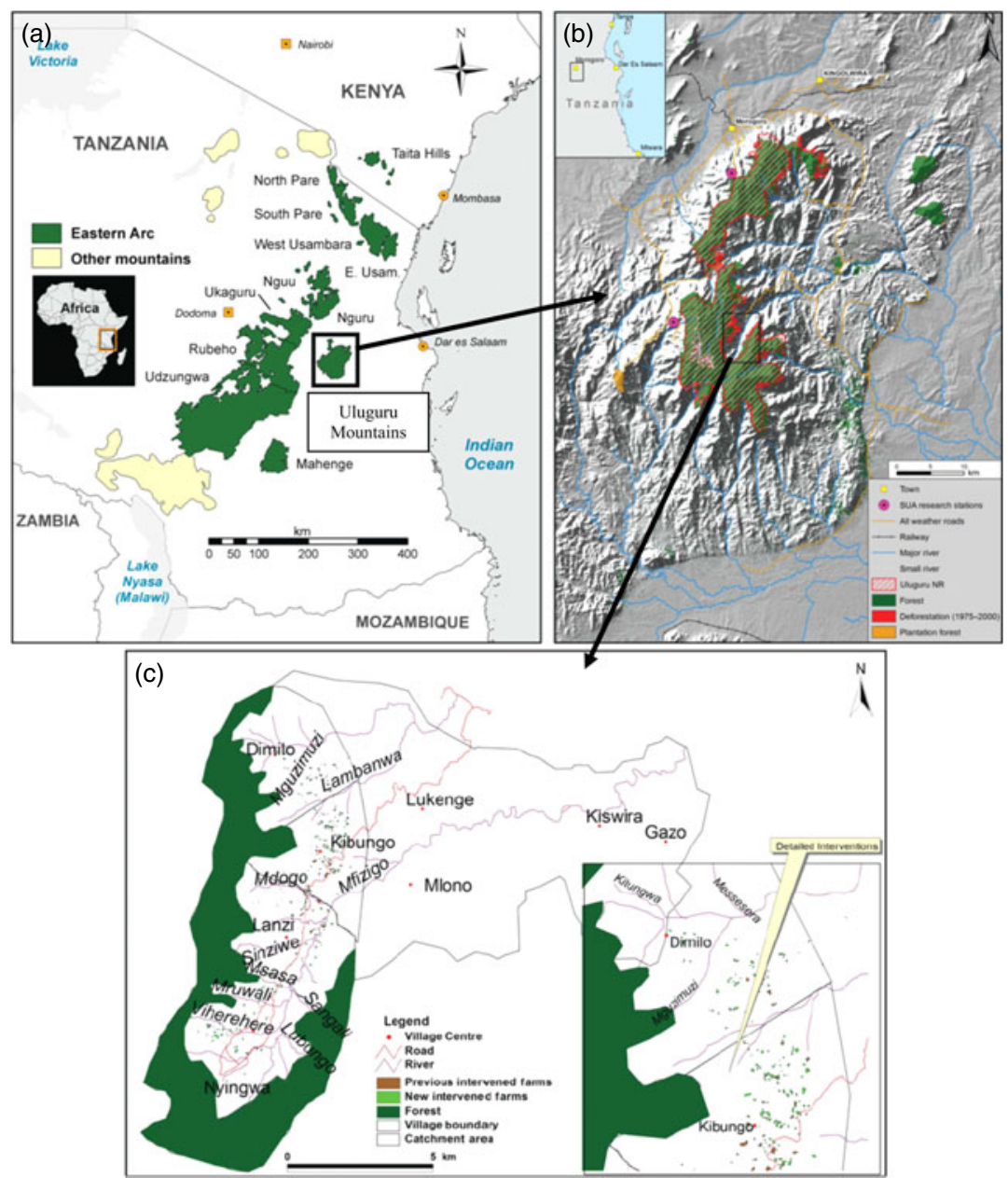

Figure 1. (a) The Eastern Arc Mountains; (b) The Uluguru Mountains showing the location of the Equitable Payments for Watershed Services program; (c) Kibungu sub-catchment with the location of villages and individual farmers' fields under project interventions (inset)

Source: Adopted from Lopa et al. (2012).

and Sewage Company (DAWASCO) and Coca Cola Kwanza Ltd were the service buyers and the Lukenge, Kibungo, Lanzi, Dimilo and Nyingwa villages were the service providers in the Kibungo juu ward (CARE/WWF, 2007). The main livelihood activities in these villages are annual crop farming, off-farm activities such as banana businesses and carrying bananas to the market, permanent crop farming, and employment as farm labor, as well as hunting and gathering.

EPWS was a voluntary program whereby the payments to service providers were conditional on the adoption of SLM practices such as 
agro-forestry, fanya $j u u^{1}$ and bench terracing to reduce nutrient mining and soil erosion and to improve rural livelihoods on over 2,240 ha of farmland (Branca et al., 2011; Lopa et al., 2012). Each farmer who participated in the EPWS program chose SLM practices that suited the slope of his / her land and received agricultural inputs and technical assistance from CARE and monetary rewards for adopted practices through village-level contracts from DAWASCO. Lopa et al. (2012) provide details of the development, operationalization, payment mechanism and sustainability of the EPWS scheme. Branca et al. (2011) used the EPWS program as a case study to explore the key challenges of PES programs in supporting the adoption of SLM practices in developing countries. This paper examines the direct and indirect, financial and non-financial livelihood impacts of the EPWS program to draw conclusions about how the livelihoods of program participants were affected when compared to non-participants.

We used a multi-method quasi-experimental approach drawing from qualitative and quantitative methods to examine the direct and indirect financial and non-financial livelihood impacts of the EPWS program. In 2011 we administered a household questionnaire to 116 program participants and 117 non-participants selected from a stratified random sample generated through a participatory wealth ranking to generate a representative sample from the EPWS program villages. The household questionnaire collected basic social and demographic data alongside data on changes in human capital variables (i.e., the amount of training attended by members of a household), social capital variables (i.e., the number of memberships and affiliations of trust), and financial capital variables (i.e., the number of livestock, crop harvests, non-agricultural salaries and remittances) (Carney, 1998; Ellis and Freeman, 2005). In addition, focus group discussions were performed with eight groups of program participants and eight groups of non-participants for triangulation purposes. Semi-structured interviews were conducted with key informants - four EPWS program staff, four village leaders, eight representatives from EPWS farmer groups in each program village and eight EPWS participating and eight nonparticipating household heads. Both key informant interviews and focus group discussions captured information on the modality, amount and use of EPWS payments and the influence of the program on the value of land and access, livestock keeping, crop yields, environmental and agricultural knowledge, local institutions and trust within and outside.

\subsection{The propensity score matching and implementation}

The propensity score matching (PSM) technique was used to construct a statistical comparison group based on balancing scores $\boldsymbol{b}(X)$ of the probability for an individual to participate in a treatment given his/her observable covariates unaffected by the program, such that the conditional distribution of $\boldsymbol{X}$ given $\boldsymbol{b}(\boldsymbol{X})$ is independent of assignment into treatment (Rosenbaum and Rubin, 1983; Rosenbaum, 2002; Caliendo and Kopeinig,

${ }^{1}$ Fanya juu is a Swahili word meaning 'throw soil upwards'. Fanya juu terraces are constructed by digging ditches and heaping the soil in the upper sides of the ditches. 
2008). This probability or propensity score is then used to match EPWS program participants to non-EPWS participants. The average treatment effect of the program is then calculated as the mean difference in outcomes across the two groups Rosenbaum and Rubin, 1983; Rosenbaum, 2002). This counterfactual condition establishes what would have happened to the livelihoods of participants if there had been no EPWS program intervention. Being an observational quasi-experimental evaluation study, the validity of PSM depends on: (a) conditional independence (namely, that unobserved factors do not affect participation); and (b) the presence of sizable common support or overlap in propensity scores across the EPWS participants and non-EPWS participants to reduce selection bias (Rosenbaum, 2002).

The choice of the model to be used for estimation of propensity score and the variables to be included in the model are two important choices that need to be made when using PSM (Dehejia and Wahba, 2002; Rosenbaum, 2002). In this study, the logit model of program participation was used to estimate probabilities or propensity scores. Any discrete choice model can be used for estimating propensity scores because logit and probit models yield similar results when estimating the probability of participation vs. non participation in binary treatment cases (Rosenbaum, 2002). In the general framework of the probability model we have: Prob(EPWS participation $)=\operatorname{Prob}(D=1)=F$ [relevant effects, parameters]. In this case, the probability of participation in EPWS is a cumulative distribution function $F$ evaluated as a function of a set $(X)$ of explanatory variables that include household socio-economic characteristics, and a vector $\beta$ of unknown parameters. The probability of participation model can be written as:

$$
\operatorname{Prob}\left(D_{i}=j\right)=\frac{e^{\beta x_{i j}}}{e^{\beta x_{i o+}} e^{\beta x_{i 1}}} \text { for } j=0,1 .
$$

The choice of variables used for building up the propensity score model were based on sound knowledge of previous research and those unaffected by participation or anticipation of it (Rosenbaum, 2002; Caliendo and Kopeinig, 2008). The variables included in the propensity score estimation model are household head's gender, age and education, household family size, farm size of the household, and household's past land use. To make sure the bias in PSM program estimates is low, the same survey instrument was administered to participants and non-participants from the same geographical area facing the same economic incentives (i.e., that might be driving choices such as program participation) to ensure that the observed characteristics entering the logit model of participation are measured similarly across the two groups (Heckman et al., 1999; Dehejia and Wahba, 2002; Ravallion, 2007; Caliendo and Kopeinig, 2008).

Nearest neighbor (NN) matching with replacement estimator (i.e., an untreated individual was used more than once as a match) was used to tradeoff bias and variance (Dehejia and Wahba, 2002; Caliendo and Kopeinig, 2008). By allowing replacement, the average quality of matching was increased and the bias decreased (Dehejia and Wahba, 2002). This approach was vital in this study because the propensity score distribution 
in the data between the treatment and the control group was slightly different. This could reduce the number of distinct non-participants used to construct the counterfactual outcome and increase the variance of the estimator (Rosenbaum and Rubin, 1983; Dehejia and Wahba, 2002). Matching with replacement allowed the reduction of bias, by producing matches of higher quality than that which could have be achieved with matching without replacement, given the lower number of control observations (Dehejia and Wahba, 2002; Scales, 2015).

Visual analysis of histograms (figures $2 \mathrm{a}$ and $2 \mathrm{~b}$ ) showing density distribution of the propensity score in the two groups was used to check the overlap and the region of common support assumption (Caliendo and Kopeinig, 2008). This ensured that any combination of characteristics observed in the treatment group can also be observed among the control group (Caliendo and Kopeinig, 2008). In NN matching with replacement, only the closest neighbor from the control group is used to match treatment individuals. Control individuals that fall outside the region of common support were discarded as bad matches (Rosenbaum and Rubin, 1983). The region of common support before NN matching with replacement is shown in figure $2 \mathrm{a}$, while figure $2 \mathrm{~b}$ shows the region after $\mathrm{NN}$ matching with replacement.

The quality of matching in terms of characteristics of the treatment and control groups before and after matching is presented in table 1, which also shows observable socio-economic characteristics used for matching that had the potential to influence participation or selection into the EPWS program (Ravallion, 2007; Caliendo and Kopeinig, 2008). Before matching, the sample shows that the heads of participating households are younger than non-participants and that they have more years of schooling. The participating households also have more members and land. Indeed, the Mann-Whitney U-test shows significant difference between the treated and control group (table 1). After matching, the treatment and control

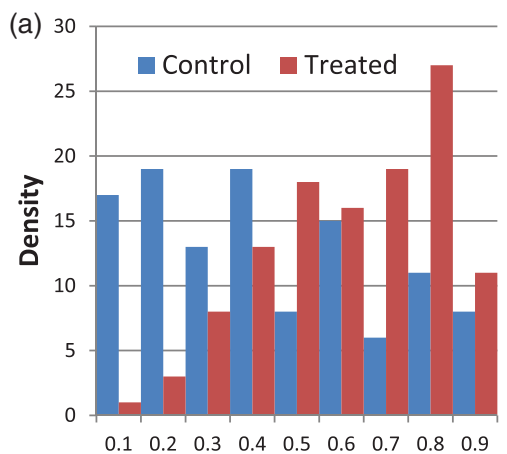

Propensity Score

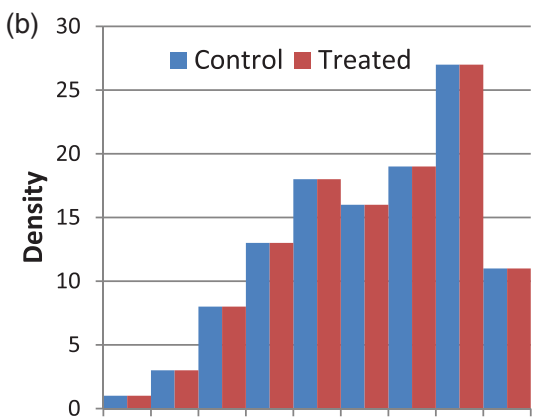

$\begin{array}{lllllllll}0.1 & 0.2 & 0.3 & 0.4 & 0.5 & 0.6 & 0.7 & 0.8 & 0.9\end{array}$

Propensity Score

Before matching

After matching

Figure 2. Regions of common support before (panel a) and after (panel b) nearest neighbor matching with replacement 
Table 1. Comparison of pre-matched and matched samples of Equitable Payments for Watershed Services (EPWS) program participants and non-participants

\begin{tabular}{|c|c|c|c|c|c|c|c|c|c|c|}
\hline \multirow[b]{2}{*}{ Names of variables } & \multirow{2}{*}{$\begin{array}{l}\text { Treatment } \\
\text { condition }\end{array}$} & \multirow[b]{2}{*}{$N$} & \multicolumn{4}{|c|}{ Before matching } & \multicolumn{4}{|c|}{ After matching } \\
\hline & & & Mean & $S D$ & $Z$ & Asymp. sig & Mean & $S D$ & $Z$ & Asymp. sig. \\
\hline \multirow[t]{2}{*}{ Gender of household head ${ }^{1}$} & No & 116 & 0.58 & 0.496 & -2.336 & 0.019 & 0.81 & 0.394 & -0.761 & 0.447 \\
\hline & Yes & 116 & 0.72 & 0.449 & & & 0.72 & 0.449 & & \\
\hline \multirow{2}{*}{ Age of household head } & No & 116 & 51.5 & 15.787 & -3.775 & 0.00 & 43.84 & 11.844 & -0.942 & 0.346 \\
\hline & Yes & 116 & 43.72 & 13.261 & & & 43.64 & 13.252 & & \\
\hline \multirow[t]{2}{*}{ Household size } & No & 116 & 2.01 & 1.176 & -3.841 & 0.00 & 2.81 & 1.215 & -0.681 & 0.496 \\
\hline & Yes & 116 & 2.55 & 1.016 & & & 2.57 & 1.023 & & \\
\hline \multirow[t]{2}{*}{ Years of schooling of the household head } & No & 116 & 5.79 & 2.394 & -3.942 & 0.00 & 7.08 & 2.191 & -0.337 & 0.736 \\
\hline & Yes & 116 & 6.74 & 2.026 & & & 6.74 & 2.026 & & \\
\hline \multirow[t]{2}{*}{ Farm size (acres) } & No & 116 & 2.47 & 1.265 & -5.368 & 0.00 & 3.38 & 1.211 & -0.648 & 0.517 \\
\hline & Yes & 116 & 3.55 & 1.439 & & & 3.53 & 1.44 & & \\
\hline \multirow[t]{2}{*}{ Past land use (conservation practices) ${ }^{a}$} & No & 116 & 0.38 & 0.487 & -2.497 & 0.013 & 0.56 & 0.498 & -0.395 & 0.693 \\
\hline & Yes & 116 & 0.54 & 0.5 & & & 0.55 & 0.499 & & \\
\hline
\end{tabular}

Notes: Yes $=$ Treated (EPWS program participants) and No = Control (EPWS program non-participants).

${ }^{a}$ Indicates a dummy variable, coded as $1=$ statement true for respondent, and $0=$ statement false for respondent; the mean for these variables is therefore a percentage of respondents. ${ }^{1}$ Gender of household head: 1 if male and 0 if female; Past land use: 1 if implemented conservation practice in the past before EPWS program and 0 otherwise. Test statistic used is Mann-Whitney U. 
groups are similar in terms of propensity scores (table 1) because the Mann-Whitney U-test shows no significant difference between the two groups.

After matching the treatment group with the control group, a simple difference approach (Baker, 2000; White and Barbu, 2006) was employed to estimate the impact of the EPWS program on the livelihoods of program participants. The impacts were analyzed using the $t$-test with SPSS for Windows. Qualitative data from focus group discussions, semistructured interviews and participant observations were manually coded (Neuendorf, 2002) and relevant quotes were extracted to support themes and interpretation of quantitative questionnaire data.

\section{Results}

According to the key informants, program participants were paid between US\$8 and US\$48 once for implementing SLM techniques, depending on the area of land dedicated to improved land management practices. The average payment was US\$11. ${ }^{2}$ The average annual household cash income of program participants and non-participants was US\$54 (Tsh85,621) and US\$42 (Tsh66,892), respectively. The EPWS payments in 2010 contributed 20 per cent of program participants' annual household cash income.

According to key informants and focus group discussions, EPWS payments were an important source of cash income. One key informant said: 'The payment I received is a large amount of cash that I can get at once' (female farmer, program participant, Lanzi village - interview statement, 2011). Another key informant explained that: 'The money I received helped to buy chickens which are an important source of meat and quick source of money to attend urgent problems such as sickness or children's school needs' (male farmer, program participant, Nyingwa village - interview statement, 2011). The payments were used to improve houses, purchase food, livestock, clothes, radios and furniture, to pay school fees and to purchase better seeds. Also, the ownership of consumer durables such as machetes $(p<0.01)$, hoes $(p<0.01)$, spades $(p<0.01)$, radios $(p<$ $0.01)$, and buckets $(p<0.01)$ was significantly higher among the program participants (figure 3 ).

In the implementation of activities introduced by the EPWS program, some wealthier participants employed other villagers for casual work such as the construction of terraces and excavation of banana and tree pits. Cash income from casual work was an indirect benefit to many more participants (31.7 per cent) than non-participants (20.7 per cent), due to more trust among program participants. Key informants explained that the average income of a casual laborer was US\$1.8 per day or US $\$ 25.7$ for 14 days for constructing terraces or excavating banana pits. Also, in each program village, three to five people employed in tree nurseries established by the program received an annual salary of about US\$441 per year.

2 In 2011, US $\$ 1=$ Tsh1,580. 


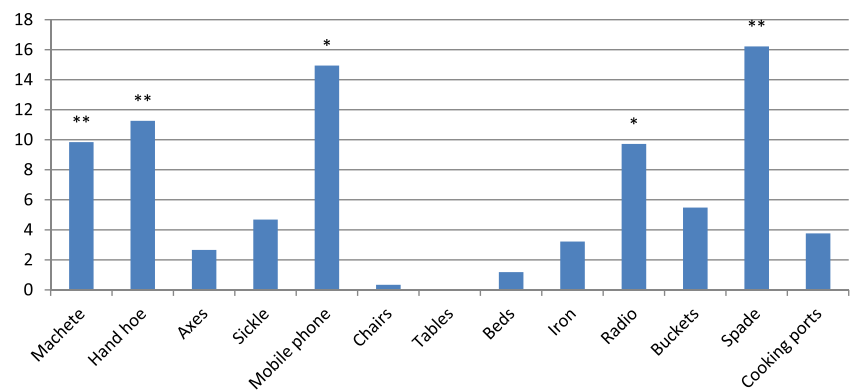

Figure 3. Equitable Payments for Watershed Services participants' ownership of consumer durables when compared to non-participants

Notes: Analysis refers to statistical independent samples t-test for differences in means of two different groups of samples. ${ }^{* *} p<0.01 ;{ }^{*} p<0.05$.

Yields of beans and cabbage are statistically larger among the treatment group. Maize, bean, groundnut, sugarcane, banana, cassava, sweet potato and tomato yields are also larger in the treatment group but the differences are not statistically significant (figure 4). Key informant interviews and focus group discussions suggested that yields increased because of the introduction of improved agricultural practices such as intercropping of maize with cover crops such as beans and groundnuts, use of improved seeds, application of animal manure, and specialization in high-value crops such as beans, tomatoes and cabbage. Compost manure was used by 69 per cent of participants and 21 per cent of non-participants.

Our findings indicate that the number of chickens $(p<0.01)$ and goats $(p<0.05)$ was much higher among the program participants (figure 5). Key informants and participants of focus group discussions explained that program participants had been encouraged to keep goats and chicken for manure, income and meat and to construct livestock sheds for them. By

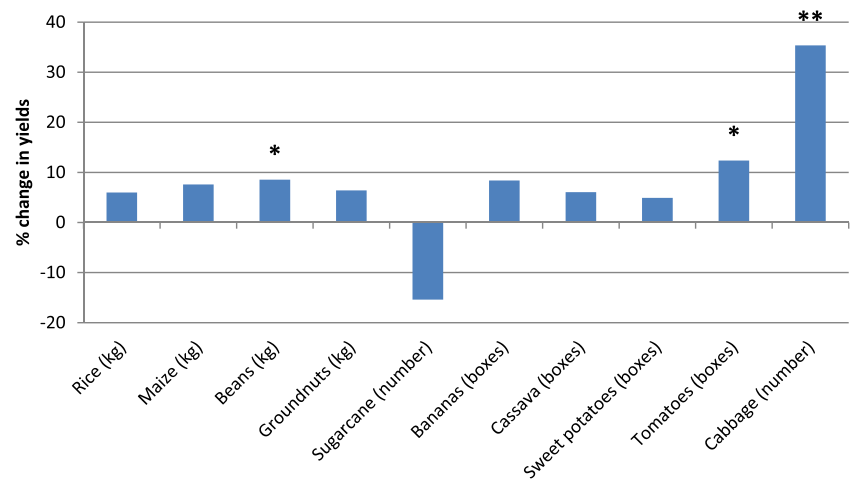

Figure 4. Outcome of Equitable Payments for Watershed Services program on average crop yields among the program participants in 2011

Notes: Analysis refers to statistical independent samples t-test for differences in means of two different groups of samples. ${ }^{* *} p<0.01 ;{ }^{*} p<0.05$. 


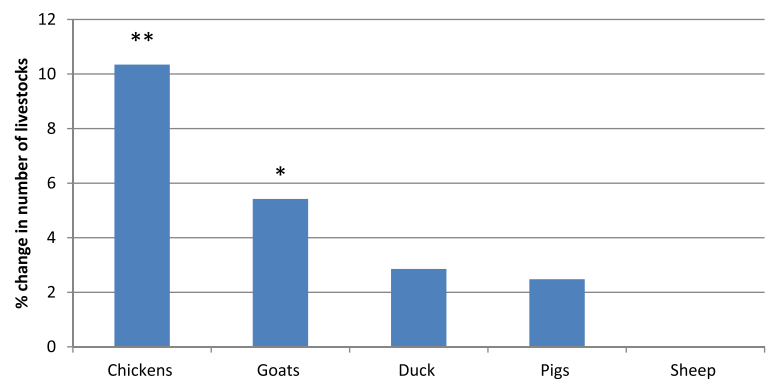

Figure 5. Outcome of the Equitable Payments for Watershed Services program in livestock keeping among program participants

Notes: Analysis refers to statistical independent samples t-test for differences in means of two different groups of samples. ${ }^{* *} p<0.01 ;{ }^{*} p<0.05$.

2011, 35 new livestock sheds had been constructed and most of the program participants had moved their goats from the forest to the sheds. In addition, some program participants had purchased goats, pigs and chickens with the PES payments they had received.

The implementation of the EPWS program activities not only increased crop yields, but also increased the amount of land farmed by 2.7 per cent among the treatment group. It also increased the value of land where SLM practices such as terraces had been introduced. A key informant explained that:

'According to our custom, anyone can go to a landholder with idle land and borrow that land either without paying or in return for an agreed share of the harvest. The program has now motivated those who used to give or lease their idle land to plant trees in order to be paid money and ... for future sale of trees or timber.' (male farmer, program participant, Nyingwa village - interview statement, 2011)

The average price of land perceived by key informants and focus group participants before the construction of terraces ranged between US $\$ 74$ and US\$216 per acre in a hilly terrain and between US\$248 and US\$496 in flat terrain. According to the key informants and focus group participants, the average price of arable land increased to US\$2,168 per acre in hilly terrain after terracing. While this increase has benefited land owners, it has reduced access to land among the landless and those with small land holdings. According to the village leaders, average land rents also increased from being free in 2008 to between US\$1.8 and US\$3 per acre per year in 2011.

We also found that program participants had improved their ability to meet household food needs more than non-participants. The proportion of participants exchanging labor for food, reducing the number of meals eaten in a day, limiting meal sizes, skipping eating for an entire day, purchasing food on credit and experiencing difficulty satisfying household food needs was lower among participants than among non-participants (figure 6). 


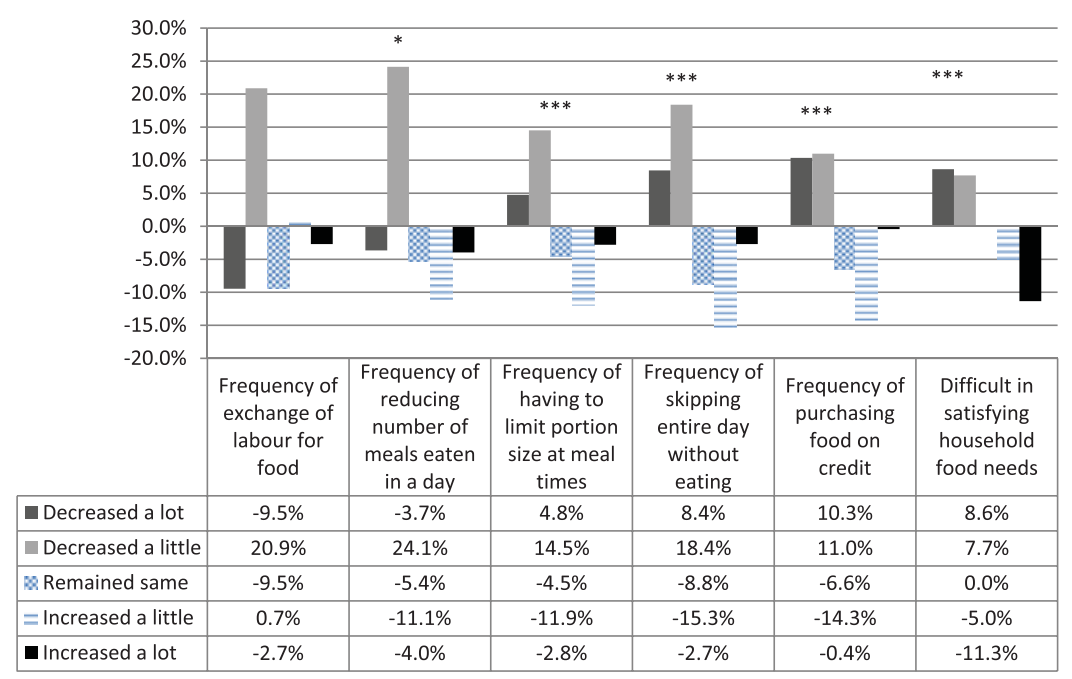

Figure 6. Household food needs of Equitable Payments for Watershed Services program participants compared to non-participants in 2011

Notes: Analysis refers to statistical independent samples t-test for differences in means of two different groups of samples from Mann-Whitney U-test. ${ }^{* * *} p<0.001$; ${ }^{*} p<$ 0.05 .

The EPWS program also had indirect non-financial impacts such as improved access to information, new and strengthened institutions and enhanced reciprocity and trust in the community, and extension of internal and external networks. About 77 per cent of program participants had received training and 86 per cent had received assistance from EPWS extension staff and the ward agricultural extension officers. Only 16 per cent of non-participants had received such support. The availability of and access to extension services was better for program participants: 83 per cent of participants and 27 per cent of non-participants considered that the availability of and access to extension services had improved, while 15 per cent of participants and 67 per cent of non-participants considered them to have remained the same. Program participants received extension services provided by the ward extension officer in addition to the EPWS program extension services, while non-participants received ward extension services only.

Another indirect non-financial impact of the program was the increased availability of environmental and agricultural information: up to 91 per cent of participants and 42 per cent of non-participants felt such information had increased; only 10 per cent of participants and 55 per cent of non-participants considered it to have remained the same. Key informants and focus group participants considered that the increase in environmental and agricultural knowledge and skills among participants was the result of their interaction with the program extension officers, as well as participation in dissemination workshops and study tours. Program participants also received support from the program-trained para-professionals (five to eight in each village) who served as local extension contacts. 
Environmental information was also disseminated in four primary schools and one secondary school. Over 10,000 trees were planted in the schools and students took trees home from the school-managed tree nurseries established through the program (EPWS program officer - interview statement, 2011).

The EPWS program also created new institutions and strengthened existing ones, improved trust in the community and expanded internal and external networks. The program established farmer groups, which in turn adopted rules to guide their operation and to achieve collective program obligations. These rules helped the farmer groups to sanction defaulters by fines or eviction. A farmer explained that if a member of our group fails to attend group work for more than two days, s/he will be required to return any group tools and pay a fine of US $\$ 12^{\prime}$ (female farmer group leader in Nyingwa village - interview statement, 2011).

The EPWS program also improved trust among the participants. Program participants have a significantly higher number of memberships $(p<$ 0.05 ) (figure 7) in all categories (figure 8). The increase in memberships after the EPWS program is more pronounced for men than women $(p<0.05)$ (figure 7). Key informants and focus group participants explained that males' involvement in community, village and external expert meetings and workshops was more common because women were more involved in daily household activities. Memberships and interactions increased their ability to work together and exchange ideas. Consequently, trust among program participants was significantly higher $(p<0.1)$. The concept of trust was defined by the key informants and focus group discussions as the ability and willingness to give and receive assistance from people beyond relatives and friends if food or money was needed. Our findings suggest that 67 per cent of participants and 44 per cent of non-participants provided help to a friend, 58 per cent of participants and 49 per cent

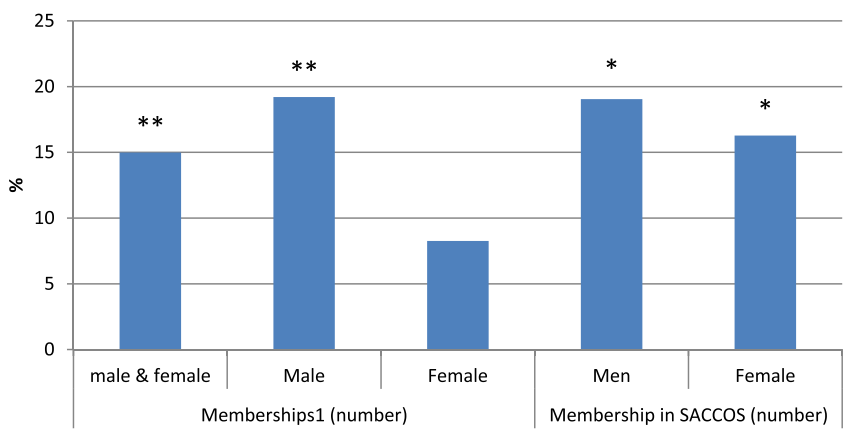

Figure 7. Percentage change in household number of memberships and in various groups among Equitable Payments for Watershed Services program participants Notes: Analysis refers to statistical independent samples t-test for differences in means of two different groups of samples. ${ }^{* *} p<0.01 ;{ }^{*} p<0.05 .{ }^{1}$ Memberships include forest management, religious-based organization, school committee, membership of savings and credit cooperative (SACCOS), non-governmental organizations (NGO), village government and Equitable Payments for Watershed Services (EPWS), village group and ward network group. 


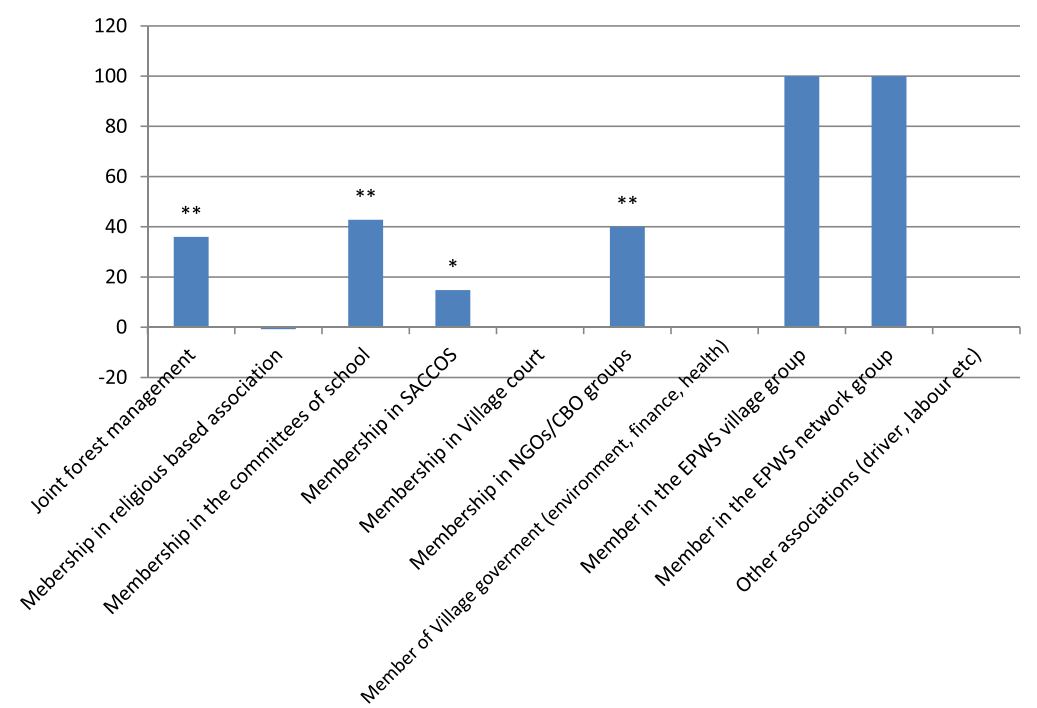

Figure 8. Change in household memberships in various groups among Equitable Payments for Watershed Services program participants

Notes: Analysis refers to statistical independent samples t-test for differences in means of two different groups of samples from Mann-Whitney U-test. ${ }^{* *} p<0.01$; ${ }^{*} p<0.05$.

of non-participants borrowed money from a friend, and 62 per cent of participants and 40 per cent of non-participants lent money to a friend or relative.

Villagers also trusted outsiders more as a result of networks expanded to national and international researchers, CARE and WWF organizations and associated program staff, extension staff, DAWASCO and Coca Cola Kwanza Ltd. and other external organizations and actors. Key informants and focus group discussions suggested that outsiders were traditionally feared and called 'chinja chinja' (i.e., killers) because of deaths and disappearances in the villages in the 1890s and early 1900s during German colonial rule. As development projects became more common in the villages, trust gradually increased. A farmer explained that 'as more people were joining and attending CARE training, and as no bad news were reported about them, and as their livelihood are improving ... I think it is worth joining and benefiting as they are benefiting' (male farmer, program non-participant, Nyingwa village - interview statement, 2011).

Nevertheless, some villagers remain concerned about the conservation intentions, particularly of land confiscation and relocation after conservation measures. One key informant explained that 'we are worried that this program has been secretly sent to the village by the government to promote tree planting which will become the property of the government' (male farmer, program participant, Kibungo village - interview statement, 2011). Some program participants and non-participants were also concerned about PES, asking 'how can someone give you trees for free and also pay you money for planting them in your own farm?' 


\section{Discussion}

We have demonstrated how the implementation of PES programs in agroecosystems of developing countries can benefit rural livelihoods by examining the direct and indirect financial and non-financial livelihood impacts of the EPWS program. Our findings suggest that the EPWS program payments make a 20 per cent direct contribution to program participants' annual cash income. These payments are one way through which a PES program can improve livelihoods (Pascual et al., 2010). The EPWS payments can be compared to payments made in PES programs implemented in Latin America: their participants have received payments amounting to between 10 and 50 per cent of their annual income (Miranda et al., 2003; Kosoy, 2008; Wunder, 2008; Bremer et al., 2014).

The additional income improved the EPWS program participants' ability to invest in houses, to purchase food, better seeds, livestock, clothes, radios and furniture and to pay school fees. Although the payments are not large enough to make a substantial difference to livelihoods, participants are mostly happy to have a PES program as a new and additional source of income (de Man, 2004) and as a means of improving income diversification and stabilization (Grieg-Gran et al., 2005; Calvet-Mir et al., 2015). A concern in many PES programs is what happens when payments end, as many developing country programs have existed for only a short time and the payments often do not extend beyond coverage of the design and start-up costs (Wunder, 2008; Tacconi et al., 2010). However, it is expected that by the end of projects, a functioning PES scheme could be in place with sellers and buyers (Tacconi et al., 2010; Martin et al., 2014; Calvet-Mir et al., 2015).

Our findings also indicate that the construction of terraces and tree planting for agro-forestry and reforestation increased the value of land enrolled in the EPWS program (Zilberman et al., 2008). This demonstrates the potential of PES to induce the adoption of improved land management practices despite being currently seldom used for this purpose (Landell-Mills and Porras, 2002; Huang et al., 2009; Martin et al., 2014). However, our findings also suggest that increased value of land can have negative consequences for the landless poor and smallholders. The land they used to access for free or at low cost can now be used by the owners to maximize their benefits from PES. German et al. (2011) also report that access to land among the landless was reduced as a result of the expansion of forest carbon sequestration in the Trees for Global Benefits Programme in the Bushenyi District in Uganda. The Cinadau PES program in Indonesia had similar outcomes (Leimona et al., 2010).

Indirect benefits of the EPWS program included increased capacity, skills and knowledge of participants and improved access to information. These impacts have also been reported from other programs. For example, in Mexico's PES programs, the training offered increased conservation awareness and created new skills such as program design and seeking of funding among participants (Corbera, 2010). Because of regular interaction with NGO staff and researchers, program participants in the Cidanau PES program in Indonesia were found to be more aware of environmental issues such as causes of erosion, downstream sedimentation, erosion prevention 
and the role of trees in water and soil conservation than non-participants (Leimona et al., 2010).

We also found that raising awareness about PES is vital because poor understanding of it raised concerns and delayed enrolment in the EPWS program. The fears of land confiscation and relocation and uncertainty about the ownership of trees demonstrated poor understanding of the PES concept. These findings have been echoed in other studies such as that of Robertson and Wunder (2005) in the Los Negros River Watershed, which indicated that farmers did not trust PES initiatives implemented in their area. Limited understanding of PES made some farmers interpret cash payments as covert attempts to buy their land (Leimona et al., 2010).

Improved trust among the program participants and internal and external networks were demonstrated as other important benefits of the EPWS program. The EPWS program's choice of establishing new, and strengthening the capacity of existing, local-level institutions through formation of farmer groups and internal and external visits and training helped to bring about the above outcomes (Lopa et al., 2012). Research on other programs has shown that PES have enhanced cohesion in communities and expanded farmer networks beyond the community (Bartels et al., 2010; Tacconi et al., 2010; Hejnowicz et al., 2014). Extended networks have been found to reduce household vulnerability and enhance welfare of the poor, both in terms of empowerment and poverty alleviation (Pagiola et al., 2005; Wunder, 2008; Hejnowicz et al., 2014). Moreover, improvement and establishment of local institutions such as farmer groups as shown in this study have been considered to reduce the transaction costs of a PES program when activities and payments are distributed in groups (Bartels et al., 2010; Tacconi et al., 2010).

\section{Conclusion}

We have examined the direct and indirect financial and non-financial livelihood impacts of the EPWS program. Our findings demonstrate that, while cash payments to participants in return for the adoption of SLM practices are important, other benefits such as training and the introduction of improved agricultural practices, improved seeds, animal manure, and high value crops and various local workshops and training are also substantial. Together they resulted in increased crop yields, value of land and employment opportunities as well as stronger institutions, increased trust, expanded internal and external networks, increased knowledge of farmers and capacity in farming, and leadership and business. These impacts are transferable assets which can underpin activities outside the PES program and thus offer potential to enhance rural development.

The perceived increase in the value of land resulted in higher land rents and reduced the availability of land, thus reducing access to land by the landless and the poor. This finding calls for greater attention to the pro-poor design of PES programs implemented on agro-ecosystems. Furthermore, there is room for more research on how the landless and smallholders cope with increased land rent and reduced access to land, to establish, for example, to what extent increased employment opportunities could compensate for reduced access to land. Given the limited research 
and recent implementation of PES programs on agro-ecosystems in developing countries, more research is also needed to fully understand the effectiveness of these programs to deliver ecosystem services and improve rural livelihoods.

\section{References}

Asquith, N.M., M.T. Vargas Ríos, and J. Smith (2002), ‘Can forest-protection carbon projects improve rural livelihoods? Analysis of the Noel Kempff Mercado Climate Action Project, Bolivia', Mitigation and Adaptation Strategies for Global Change 7(4): 323-337.

Asquith, N.M., M.T. Vargas, and S. Wunder (2008), 'Selling two environmental services: in-kind payments for bird habitat and watershed protection in Los Negros, Bolivia', Ecological Economics 65(4): 675-684.

Baker, J.L. (2000), Evaluating the Impact of Development Projects on Poverty: A Handbook for Practitioners, Washington, DC: World Bank.

Bartels, W.L., M. Schmink, H.D.S.S. Arcos, E.A. Borges, and A.P. Duarte (2010), 'Diversifying livelihood systems, strengthening social networks, and rewarding environmental stewardship among small-scale producers in the Brazilian Amazon: lessons from Proambiente', in L. Tacconi, S. Mahanty and H. Suich (eds), Payments for Environmental Services, Forest Conservation and Climate Change: Livelihoods in the REDD?, Cheltenham: Edward Elgar, pp. 82-105.

Branca, G., L. Lipper, B. Neves, D. Lopa, and I. Mwanyoka (2011), 'Payments for watershed services supporting sustainable agricultural development in Tanzania', Journal of Environment and Development 20(3): 278-302.

Bremer, L.L., K.A. Farley, D. Lopez-Carr, and J. Romero (2014), 'Conservation and livelihood outcomes of payment for ecosystem services in the Ecuadorian Andes: what is the potential for "win-win"?', Ecosystem Services 8: 148-165.

Brockington, D. (2011), 'Ecosystem services and fictitious commodities', Environmental Conservation 38(4): 367-369.

Brown, D.R., P. Dettmann, T. Rinaudo, H. Tefera, and A. Tofu (2011), ‘Poverty alleviation and environmental restoration using the clean development mechanism: a case study from Humbo, Ethiopia', Environmental Management 48(2): 322-333.

Bulte, E.H., L. Lipper, R. Stringer, and D. Zilberman (2008), 'Payments for ecosystem services and poverty reduction: concepts, issues, and empirical perspectives', Environment and Development Economics 13(3): 245-254.

Caliendo, M. and S. Kopeinig (2008), 'Some practical guidance for the implementation of propensity score matching', Journal of Economic Surveys 22(1): 31-72.

Calvet-Mir, L., E. Corbera, A. Martin, J. Fisher, and N. Gross-Camp (2015), 'Payments for ecosystem services in the tropics: a closer look at effectiveness and equity', Current Opinion in Environmental Sustainability 14: 150-162.

Caplow, S., P. Jagger, K. Lawlor, and E. Sills (2011), 'Evaluating land use and livelihood impacts of early forest carbon projects: lessons for learning about REDD+', Environmental Science and Policy 14(2): 152-167.

CARE/WWF (2007), Social and Livelihoods Assessment for Villages Around East Usambara and Uluguru Mountains, Dar-es-Salaam: CARE International.

Carney, D. (1998), 'Implementing the sustainable rural livelihoods approach', in D. Carney (ed.), Sustainable Rural Livelihoods: What Contribution Can We Make?, London: Department for International Development.

Chambers, R. and G. Conway (1992), 'Sustainable rural livelihoods: practical concepts for the 21st Century', Discussion Paper No. 296, Institute of Development Studies, Sussex. 
Clot, S., F. Andriamahefazafy, G. Grolleau, L. Ibanez, and P. Méral (2014), 'Payments for ecosystem services: can we kill two birds with one stone? Insights from a natural field experiment in Madagascar', Document de Recherché 2014-1, LAMETA, Universite Montpellier 1.

Cole, R.J. (2010), 'Social and environmental impacts of payments for environmental services for agroforestry on small-scale farms in southern Costa Rica', International Journal of Sustainable Development and World Ecology 17(3): 208-216.

Corbera, E. (2010), 'Mexico's PES-carbon programme: a preliminary assessment and impacts on rural livelihoods', in L. Tacconi, S. Mahanty and H. Suich (eds), Payments for Environmental Services, Forest Conservation and Climate Change: Livelihoods in the REDD?, Cheltenham: Edward Elgar, pp. 54-81.

Corbera, E. and U. Pascual (2012), 'Ecosystem services: heed social goals', Science 335: 655-656.

Corbera, E., N. Kosoy, and M. Martínez Tuna (2007), ‘The equity implications of marketing ecosystem services in protected areas and rural communities: case studies from Meso-America', Global Environmental Change 17(3-4): 365-380.

Corbera, E., C.G. Soberanis, and K. Brown (2009), 'Institutional dimensions of Payments for Ecosystem Services: an analysis of Mexico's carbon forestry programme', Ecological Economics 68(3): 743-761.

Dehejia, R.H. and S. Wahba (2002), 'Propensity score-matching methods for nonexperimental causal studies', Review of Economics and Statistics 84(1): 151-161.

de Man, M. (2004), ‘Local impacts and effectiveness of payments for environmental services in Costa Rica: the case of payments for forest hydrological services in Costa Rica's Aranjuez watershed', Utretch University, TC Utrecht.

Dempsey, J. and M.M. Robertson (2012), 'Ecosystem services: tensions, impurities, and points of engagement within neoliberalism', Progress in Human Geography 36: 758-779.

Echavarria, M., J. Vogel, M. Albán, and F. Meneses (2002), 'Impact assessment of watershed environmental services: emerging lessons from Pimampiro and Cuenca', London: International Institute for Environment and Development (IIED).

Ellis, F. and H. Freeman (2005), 'Conceptual framework and overview of themes', in F. Ellis and H. Freeman (eds), Rural Livelihoods and Poverty Reduction Policies, New York: Routledge, pp. 3-15.

Engel, S., S. Pagiola, and S. Wunder (2008), 'Designing payments for environmental services in theory and practice: an overview of the issues', Ecological Economics 65(4): 663-674.

FAO (2007a), Paying Farmers for Environmental Services: The State of Food and Agriculture, 2007, Rome: Food and Agriculture Organization of the United Nations.

FAO (2007b), State of the World's Forests, 2007, Rome: Food and Agriculture Organization of the United Nations.

Ferraro, P.J. (2009), 'Regional review of payments for watershed services: SubSaharan Africa', Journal of Sustainable Forestry 28(3): 525-550.

Ferraro, P.J. and S.K. Pattanayak (2006), 'Money for nothing? A call for empirical evaluation of biodiversity conservation investments', PLoS Biology 4(4): e105.

Ferraro, P.J. and R.D. Simpson (2002), 'The cost-effectiveness of conservation payments', Land Economics 78(3): 339-353.

German, L., A. Ruhweza, R. Mwesigwa, and C. Kalanzi (2011), 'Social and environmental footprints of carbon payments: a case study from Uganda', in L. Tacconi, S. Mahanty and H. Suich (eds), Payments for Environmental Services, Forest Conservation and Climate Change: Livelihoods in the REDD?, Cheltenham: Edward Elgar, pp. 160-184. 
Grieg-Gran, M., I. Porras, and S. Wunder (2005), 'How can market mechanisms for forest environmental services help the poor? Preliminary lessons from Latin America', World Development 33(9): 1511-1527.

Heckman, J.J., R.J. LaLonde, and J.A. Smith (1999), 'The economics and econometrics of active labor market programs', in O. Ashenfelter and D. Card (eds), Handbook of Labor Economics, vol. 3A, New York: North Holland, pp. 1865-2097.

Hejnowicz, A.P., D.G. Raffaelli, M.A. Rudd, and P.C.L. White (2014), 'Evaluating the outcomes of payments for ecosystem services programmes using a capital asset framework', Ecosystem Services 9: 83-97.

Hope, R., I. Porras, M. Miranda, C. Agarwal, and J. Amezaga (2005), 'Are the upland poor benefiting from environmental service reward schemes', ETFRN News.

Huang, M., S. Upadhyaya, R. Jindal, and J. Kerr (2009), 'Payments for watershed services in Asia: a review of current initiatives', Journal of Sustainable Forestry 28(3): 551-575.

Intergovernmental Panel on Climate Change (2007), 'Summary for policymakers', in B. Metz, O.R. Davidson, P.R. Bosch, R. Dave and L.A. Meyer (eds), Climate Change 2007: Mitigation of Climate Change, Cambridge: Cambridge University Press, $1-24$.

Jindal, R. (2006), 'Carbon sequestration projects in Africa: potential benefits and challenges to scaling up', Earth Trends Environmental Essay Competition Winner. Washington, DC: World Resources Institute.

Kosoy, N., E. Corbera, and K. Brown (2008), 'Participation in payments for ecosystem services: case studies from the Lacandon rainforest, Mexico', Geoforum 39(6): 2073-2083.

Landell-Mills, N. and I.T. Porras (2002), Silver Bullet or Fools' Gold? A Global Review of Markets for Forest Environmental Services and their Impact on the Poor, London: International Institute for Environment and Development (IIED).

Leimona, B., R. Pasha, and N. Rahadian (2010), 'The livelihood impacts of incentive payments for watershed management in Cidanau watershed, West Java, Indonesia', in L. Tacconi, S. Mahanty and H. Suich (eds), Payments for Environmental Services, Forest Conservation and Climate Change: Livelihoods in the REDD?, Cheltenham: Edward Elgar, pp. 106-129.

Liniger, H., R.M. Studer, C. Hauert, and M. Gurtner (2011), Sustainable Land Management in Practice - Guidelines and Best Practices for Sub-Saharan Africa, Midrand: TerrAfrica; Berne: WOCAT; Rome: FAO.

Locatelli, B., V. Rojas, and Z. Salinas (2008), 'Impacts of payments for environmental services on local development in northern Costa Rica: a fuzzy multi-criteria analysis', Forest Policy and Economics 10(5): 275-285.

Lopa, D., I. Mwanyoka, G. Jambiya, et al. (2012), 'Towards operational payments for water ecosystem services in Tanzania: a case study from the Uluguru Mountains', Oryx 46(1): 34-44.

Martin, A., N. Gross-Camp, B. Kebede, and S. McGuire (2014), 'Measuring effectiveness, efficiency and equity in an experimental Payments for Ecosystem Services trial', Global Environmental Change 28: 216-226.

Matzdorf, B. and C. Meyer (2014), 'The relevance of the ecosystem services framework for developed countries' environmental policies: a comparative case study of the US and EU', Land Use Policy 38: 509-521.

McAfee, K. and E.N. Shapiro (2010), 'Payments for ecosystem services in Mexico: nature, neoliberalism, social movements, and the state', Annals of the Association of American Geographers 100: 579-599.

Miles, L. and V. Kapos (2008), 'Reducing greenhouse gas emissions from deforestation and forest degradation: global land-use implications', Science 320(5882): 1454-1455. 
Miranda, M., I.T. Porras, and M.L. Moreno (2003), 'The social impacts of payments for environmental services in Costa Rica. A quantitative field survey and analysis of the Virilla watershed', International Institute for Environment and Development, London.

Molnar, A., M. Liddle, C. Bracer, A. Khare, A. White, and J. Bull (2008), 'Communitybased forest enterprises: their status and potential in tropical countries', ITTO Technical Series No. 28, International Tropical Timber Organization, Yokohama.

Muradian, R., E. Corbera, U. Pascual, N. Kosoy, and P.H. May (2010), 'Reconciling theory and practice: an alternative conceptual framework for understanding payments for environmental services', Ecological Economics 69(6): $1202-1208$.

Neuendorf, K.A. (2002), The Content Analysis Guidebook, New York: Sage.

Pagiola, S. (2005), Assessing the Efficiency of Payments for Environmental Services Programs: A Framework for Analysis, Washington, DC: World Bank.

Pagiola, S. and G. Platais (2007), Payments for Environmental Services: From Theory to Practice, Washington, DC: World Bank.

Pagiola, S., A. Arcenas, and G. Platais (2005), 'Can payments for environmental services help reduce poverty? An exploration of the issues and the evidence to date from Latin America', World Development 33(2): 237-253.

Pascual, U., R. Muradian, L.C. Rodríguez, and A. Duraiappah (2010), 'Exploring the links between equity and efficiency in payments for environmental services: a conceptual approach', Ecological Economics 69(6): 1237-1244.

Pattanayak, S., (2009), 'Rough guide to impact evaluation of environmental and development programs', SANDEE Working Paper No. 40-09, Kathmandu.

Porras, I., M. Grieg-Gran, and N. Neves (2008), 'All that glitters: a review of payments for watershed services in developing countries', International Institute for Environment and Development, London.

Ravallion, M. (2007), 'Evaluating anti-poverty programs', in T.P. Schultz and J. Strauss (eds), Handbook of Development Economics, Volume 4, Amsterdam: North Holland, pp. 3787-3846.

Redford, K.H. and W.M. Adams (2009), 'Payment for ecosystem services and the challenge of saving nature', Conservation Biology 23(4): 785-787.

Robertson, N. and S. Wunder (2005), Fresh Tracks in the Forest: Assessing Incipient Payments for Environmental Services Initiatives in Bolivia, Bogor, Indonesia: Center for International Forestry Research (CIFOR).

Rosenbaum, P.R. (2002), Observational Studies, New York: Springer.

Rosenbaum, P.R. and D.B. Rubin (1983), 'The central role of the propensity score in observational studies for causal effects', Biometrika 70(1): 41-55.

Scales, I.R. (2015), 'Paying for nature: what every conservationist should know about political economy', Oryx 49(2): 226-231.

Schomers, S. and B. Matzdorf (2013), 'Payments for ecosystem services: a review and comparison of developing and industrialized countries', Ecosystem Services 6: 16-30.

Singh, N.M. (2015), 'Payments for ecosystem services and the gift paradigm: sharing the burden and joy of environmental care', Ecological Economics 117: 53-61.

Smith, H.F. and C.A. Sullivan (2014), 'Ecosystem services within agricultural landscapes - farmers' perceptions', Ecological Economics 98: 72-80.

Sommerville, M.M., J.P.G. Jones, and E. Milner-Gulland (2009), 'A revised conceptual framework for payments for environmental services', Ecology and Society 14(2): 34 .

Stevenson, J.R., R. Serraj, and K.G. Cassman (2014), 'Evaluating conservation agriculture for small-scale farmers in Sub-Saharan Africa and South Asia', Agriculture, Ecosystems and Environment 187: 1-10. 
Tacconi, L., S. Mahanty, and H. Suich (eds) (2010), Payments for Environmental Services, Forest Conservation and Climate Change: Livelihoods in the REDD?, Cheltenham: Edward Elgar.

Tacconi, L., S. Mahanty, and H. Suich (2011), 'PES schemes' impacts on livelihoods and implications for REDD activities', in L. Tacconi, S. Mahanty and H. Suich (eds), Payments for Environmental Services, Forest Conservation and Climate Change: Livelihoods in the REDD?, Cheltenham: Edward Elgar, pp. 244-260.

Tachibana, T. and S. Adhikari (2009), 'Does community-based management improve natural resource condition? Evidence from the forests in Nepal', Land Economics 85(1): 107-131.

TerrAfrica (2007), 'Strategic Investment Program for sustainable land management in sub- Saharan Africa (SIP)', Washington, DC: TerrAfrica Secretariat.

Vatn, A. (2010), 'An institutional analysis of payments for environmental services', Ecological Economics 69(6): 1245-1252.

White, H. and A. Barbu (2006), 'Impact evaluation - the experience of the independent evaluation group of the World Bank', Washington, DC: World Bank.

Wunder, S. (2005), 'Payments for environmental services: some nuts and bolts', CIFOR Occasional Paper No. 42, Center for International Forestry Research, Bogor.

Wunder, S. (2006), 'Are direct payments for environmental services spelling doom for sustainable forest management in the tropics?', Ecology and Society 11(2): 23.

Wunder, S. (2007), 'The efficiency of payment for environmental services in tropical conservation', Conservation Biology 21(1): 48-58.

Wunder, S. (2008), 'Payments for environmental services and the poor: concepts and preliminary evidence', Environment and Development Economics 13(3): 279-297.

Wunder, S. (2015), 'Revisiting the concept of payments for environmental services', Ecological Economics 117: 234-243.

Wunder, S. and M. Albán (2008), 'Decentralized payments for environmental services: the cases of Pimampiro and PROFAFOR in Ecuador', Ecological Economics 65(4): 685-698.

Wunder, S., S. Engel, and S. Pagiola (2008), 'Taking stock: a comparative analysis of payments for environmental services programs in developed and developing countries', Ecological Economics 65(4): 834-852.

Wunder, S., A. Angelsen, and B. Belcher (2014), 'Forests, livelihoods, and conservation: broadening the empirical base', World Development 64, Suppl. 1: S1-S11.

Zilberman, D., L. Lipper, and N. McCarthy (2008), 'When could payments for environmental services benefit the poor?', Environment and Development Economics 13: 255-278. 